\title{
ANALISA POTENSI LIKUIFAKSI BERDASARKAN DATA PENGUJIAN SONDIR (STUDI KASUS GOR HAJI AGUS SALIM DAN LAPAI, PADANG)
}

\author{
Hendri Gusti Putra ${ }^{1}$, Abdul Hakam ${ }^{2}$, Dody Lastaruna ${ }^{3}$
}

\begin{abstract}
ABSTRAK
Likuifaksi (liquefaction) merupakan salah satu bahaya yang ditimbulkan dari gempa bumi. Pada saat gempa terjadi, tanah mengalami perubahan sifat dari solid ke liquid akibat beban siklik yang diterima. Untuk itu, diperlukan suatu metode yang mudah dan sederhana untuk mengevaluasi potensi perilaku likuifaksi pada tanah, yang dapat diterapkan di kota Padang dan Sumatera Barat secara umumnya. Salah satunya adalah metode analisa potensi likuifaksi menggunakan data pengujian sondir di lapangan. Metode yang dititik beratkan kepada korelasi data perlawanan konus terhadap cyclic stress ratio dalam suatu grafik sederhana (Seed dan Idriss) yang menunjukkan batasan tanah mengalami likuifaksi atau tidak. Grafik dapat menunjukkan variasi nilai kritis uji sondir terhadap potensi likuifaksi telah dikembangkan untuk beberapa variasi terahadap magnitude gempa dan percepatan maksimum tanah serta pengaruh level muka air tanah. Dari hasil penelitian yang dilakukan, menunjukkan daerah penelitian yaitu GOR Haji Agus Salim dan Lapai, Padang, memiliki nilai faktor keamanan yang sangat kecil $(<0,5)$, dibandingkan dengan faktor keamanan yang telah ditetapkan, yaitu 1,50 . Hal ini berati bahwa daerah penelitian memiliki potensi besar terhadap likuifaksi.
\end{abstract}

Kata Kunci : gempa bumi, likuifaksi, normalisasi perlawanan kerucut, in-situ test.

\section{PENDAHULUAN}

\subsection{Latar Belakang}

Sumatera Barat khususnya kota Padang, merupakan daerah yang memiliki potensi sangat besar terhadap gempa. Sehingga hal ini menjadi perhatian khusus bagi kita semua. Maka diperlukan suatu peneltian khusus mengenai bahaya gempa ini. Salah satu permasalahan yang ditimbulkan gempa adalah bahaya likuifaksi. Bahaya likuifaksi yang ditimbulkan oleh gempa dan karakteristik tanah tertentu, yang mengakibatkan naik tegangan air pori tanah itu sendiri. Saat likuifaksi berlangsung, kekuatan tanah menurun dan kemampuan deposit tanah untuk menahan beban menurun. Tegangan efektif tanah akibat beban siklik yang diterima tanah dengan karakteristik berbutir, jenuh air dan kepadatan sedang sampai lepas, dimana tanah tersebut mengalami perubahan sifat dari solid ke liquid. Hal ini menyebabkan kerusakan pada bangunan sipil, seperti keruntuhan. Peristiwa likuifaksi ini telah dibuktikan melalui sejarah yang telah terjadi di dunia, seperti pada gempa di Niagata, Jepang pada tahun 1964.

Melihat potensi yang ditimbulkan oleh likuifaksi saat besar bagi kita, para ahli mulai mengembangkan beberapa metode praktis untuk menganalisa potensi likuifaksi dari tanah. Terdapat beberapa metode analisa likuifaksi yang telah ada, salah satunya adalah metode analisa

\footnotetext{
${ }^{1}$ Staf Pengajar Jurusan Teknik Sipil Fakultas Teknik Universitas Andalas, e-mail: hendrigp@ft.unand.ac.id

${ }^{2}$ Staf Pengajar Jurusan Teknik Sipil Fakultas Teknik Universitas Andalas, e-mail: ahakam@ft.unand.ac.id

${ }^{3}$ Mahasiswa Jurusan Teknik Sipil Fakultas Teknik Universitas Andalas
} 
menggunakan data pengujian lapangan, seperti uji sondir (cone penetration test), uji standar penetrasi, uji boring dan uji Swedish. Selain itu analisa potensi likuifaksi juga dapat dilakukan berdasarkan uji di laboratorium seperti analisa butiran. Dari sekian banyak metode yang ada, metode menggunakan data uji SPT merupakan metode yang sering digunakan oleh para ahli, seperti Seed dan Idriss (1971), Tatsuoka (1980) ,Tokimatsu dan Yoshimi (1983). Namun saat ini metode yang cocok digunakan untuk analisa likuifaksi bagi daerah Sumatera Barat adalah metode analisa potensi likuifaksi menggunakan data uji sondir. Hal ini berdasarkan dari kemudahan dalam pelaksanaan dan biaya dari uji sondir. Dan juga uji sondir lebih sering digunakan di Sumatera Barat sebagai investigasi tanah di lapangan.

\subsection{Tujuan dan Manfaat}

Adapun tujuan dari penelitian ini adalah untuk menganalisa stabilitas tanah terhadap likuifaksi. Selain itu juga mendapatkan gambaran kondisi keadaan tanah lokasi penelitian terhadap potensi likuifaksi yang mungkin terjadi berdasarkan gempa Padang Pariaman tanggal 30 September 2009 yang lalu. Selain itu, hasil penelitian dapat dijadikan bahan pertimbangan dalam kegiatan perencanaan bangunan sipil di kemudian hari.

Diharapkan melalui penelitian ini, dapat dijadikan sebagai referensi untuk menganalisa bahaya likuifaksi yang mungkin terjadi di kota Padang, sehingga diperoleh suatu angka keamanan dan karaterisktik tanah yang memiliki potensial terhadap bahayanya likuifaksi. Dan juga diharapkan penelitian ini dapat berguna sebagai sumber pengetahuan bagi masyarakat umum mengenai bahaya likufaksi.

\subsection{Batasan Masalah}

Batasan pembahasan dari penelitian ini adalah :

1. Analisa likuifaksi dibatasi di daerah penelitian yaitu GOR Haji Agus Salim dan Lapai.

2. Analisa dilakukan berdasarkan hasil uji sondir yang didapat di daerah penelitian.

3. Metode perhitungan yang digunakan dalam analisa potensi likuifaksi dengan menggunakan data uji sondir yang telah dikenalkan oleh ahli geoteknik seperti Seed dan Idriss (1971).

\section{TINJAUAN PUSTAKA}

\subsection{Umum}

Likuifaksi didefinisikan sebagai transformasi material granular dari bentuk solid menjadi cair sebagai akibat dari naiknya tekanan air pori dan kehilangan tegangan efektif (Marcuson, 1978). Naiknya tekanan air pori ini disebabkan oleh kecenderungan dari material berbutir untuk menjadi padat akibat cyclic shear deformations.

\subsection{Evaluasi Likuifaksi dan Masalah yang Ditimbulkannya}

Potensi likuifaksi pada suatu deposit tanah akan ditentukan oleh kombinasi beberapa komponen, antara lain :

a. Indeks properties tanah, seperti modulus dinamis, karakteristik kelembaban, berat volume, gradasi butiran, kepadatan relatif dan struktur tanah itu sendiri.

b. Faktor lingkungan, seperti jenis formasi tanah, sejarah seismik dan geologi, level muka air tanah dan tegangan efektif tanah.

c. Karakteristik gempa, seperti intensitas guncangan pada tanah dan lama guncangan yang terjadi. 
Dari beberapa faktor yang telah disebutkan di atas, tidak semua dari faktor tersebut dapat ditentukan besarannya secara langsung, akan tetapi dampak yang muncul dari ketiga faktor tersebut dapat digunakan atau dimasukkan kedalam prosedur evaluasi potensial likuifaksi, yaitu dengan melakukan uji beban siklik pada sampel tanah tak terganggu atau bisa juga dengan cara pengukuran karakteristik likuifaksi pada tanah menggunakan beberapa prosedur pengujian di lapangan. Pada dasarnya, prosedur standar evaluasi likuifaksi, antara lain:

a. Menentukan besaran tegangan siklik yang muncul akibat pergerakan tanah pada saat gempa bumi, pada setiap kedalaman deposit tanah dan mengkonversi bentuk tegangan yang tidak beraturan tersebut hingga memiliki besaran yang sama dalam bentuk tegangan siklik. Dengan kata lain, intensitas guncangan, lama guncangan dan variasi guncangan yang terjadi akibat tegangan pada setiap kedalaman diubah menjadi suatu besaran yang dapat dihitung. Penentuan besaran tegangan siklik yang terjadi dapat dilakukan dengan cara menganalisa respon tanah terhadap tegangan yang terjadi dengan melibatkan berat sendiri tanah, modulus dinamik dan karakteristik kelembaban.

b. Menentukan besaran tegangan siklik dengan cara uji pembebanan di laboratorium yang diwakili oleh sampel tak terganggu yang dilakukan dengan variasi tekanan bebas yang telah ditentukan atau dengan cara mengkorelasikan properties tanah dengan karakteristik tanah di lapangan.

c. Membandingkan antara tegangan geser yang terjadi akibat gempa bumi dengan hal-hal yang dapat menyebabkan terjadinya likuifaksi untuk menentukan apakah deposit tanah berada dalam zona likuifaksi atau tidak, seperti yang ditunjukkan oleh Gambar 1.

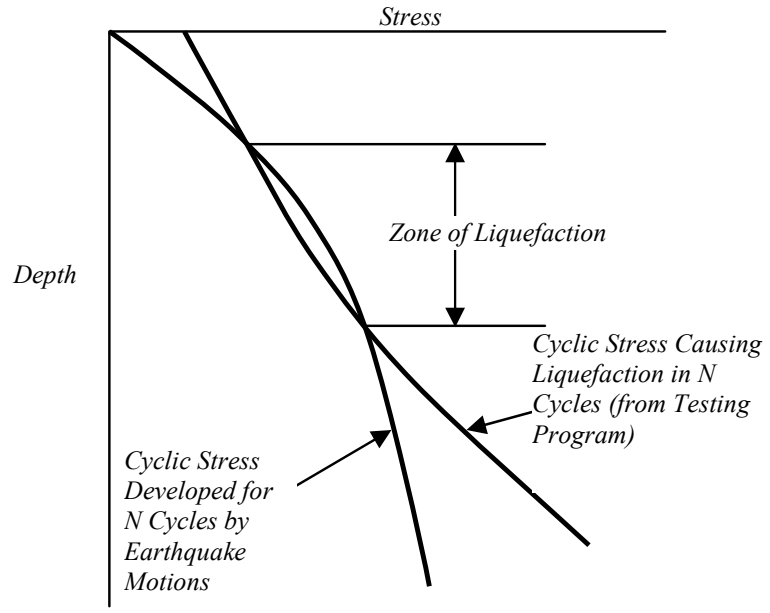

Gambar 1. Metode Evaluasi Potensi Likuifaksi

Sebagaimana yang telah dijelaskan bahwa perilaku likuifaksi pada tanah bersifat merusak dan menimbulkan dampak negatif yang besar terhadap stabilitas tanah dan bangunan diatasnya. Adapun dampak yang ditimbulkan dari perilaku likuifaksi adalah :

1. Terjadinya penurunan tanah hingga $5 \%$ ketebalan lapisan tanah terlikuifaksi.

2. Terjadinya kehilangan daya dukung lateral tanah.

3. Terjadinya kehilangan daya dukung tanah.

4. Terjadinya pengapungan struktur yang dibenamkan dalam tanah, seperti tanki di bawah tanah.

5. Meningkatkan tekanan lateral tanah yang dapat menyebabkan kegagalan pada struktur penahan tekanan lateral tanah, seperti quay walls.

6. Terjadinya lateral spreading (limited lateral movements).

7. Terjadinya lateral flow (extensive lateral movements). 


\subsection{Parameter Likuifaksi}

Parameter likuifaksi merupakan parameter yang digunakan sebagai dasar dalam menentukan kriteria likuifaksi yang terjadi pada deposit tanah. Dimana dalam hal ini, perilaku likuifaksi pada tanah dipengaruhi oleh dua parameter utama, yaitu perlawanan terkoreksi $\left(q_{c 1}\right)$ dan rasio tegangan siklik (CSR). Perhitungan nilai perlawanan terkoreksi $q_{c 1}$, dirumuskan oleh Seed dan Idriss (1971) sebagai berikut :

dimana :

$$
q_{c 1}=C_{1} \times q_{c}=C N q_{c}\left(\mathrm{~kg} / \mathrm{cm}^{2}\right)
$$

$$
\begin{aligned}
& q_{c 1}=\text { perlawanan konus tekoreksi } \\
& q_{c}=\text { perlawanan konus } \\
& C N=\text { faktor koreksi }
\end{aligned}
$$

Untuk faktor koreksi ditentukan hubungan antara tengangan efektif tanah dan $C N$ pada gambar. Seed dan Idriss (1971) merumuskan persamaan perhitungan nilai CSR tanah, yaitu :

$$
C S R=0,65 \times\left(\frac{a_{\max } \times \sigma_{o}}{g \times \sigma_{o}^{\prime}}\right) \times r_{d}
$$

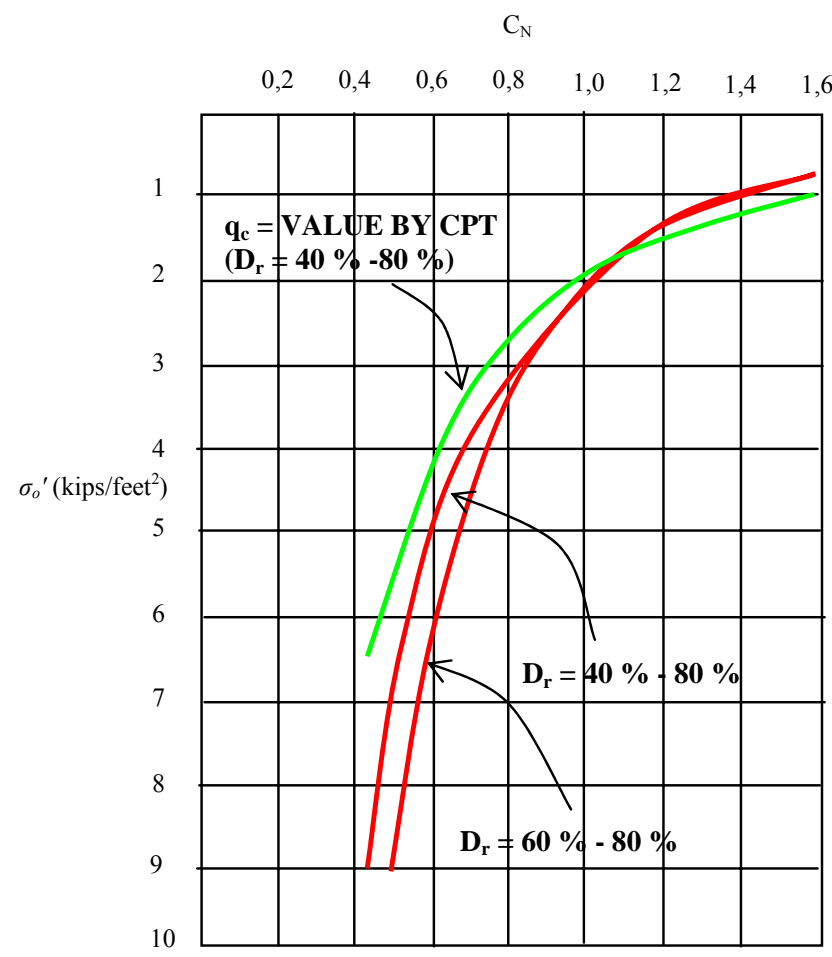

Gambar 2. Grafik Hubungan CN dan Tegangan Efeketif Tanah (Ground Motion and Soil Liquifaction during Earthquakes, Seed \& Idriss, 1982)

Dimana $r_{d}$ merupakan koefisien reduksi tegangan pada suatu kedalaman yang dirumuskan untuk mengestimasi besarnya koefisien reduksi besaran CSR.

Formulasi untuk mengestimasi koefisien reduksi tegangan (Blake, 1996) yaitu:

$$
r_{d}=\frac{1,0-0,4113 z^{1,5}+0,04052 z+0,001753 z^{1,5}}{1,0-0,4177 z^{0,5}+0,05729 z-0,006205 z^{1,5}+0,00121 z^{2}}
$$


Seed dan Idriss (1971), menentukan potensi likuifaksi berdasarkan grafik pada Gambar 3 dan Gambar 4. Grafik tersebut merupakan hubungan antara CSR dan perlawanan konus terkoreksi.

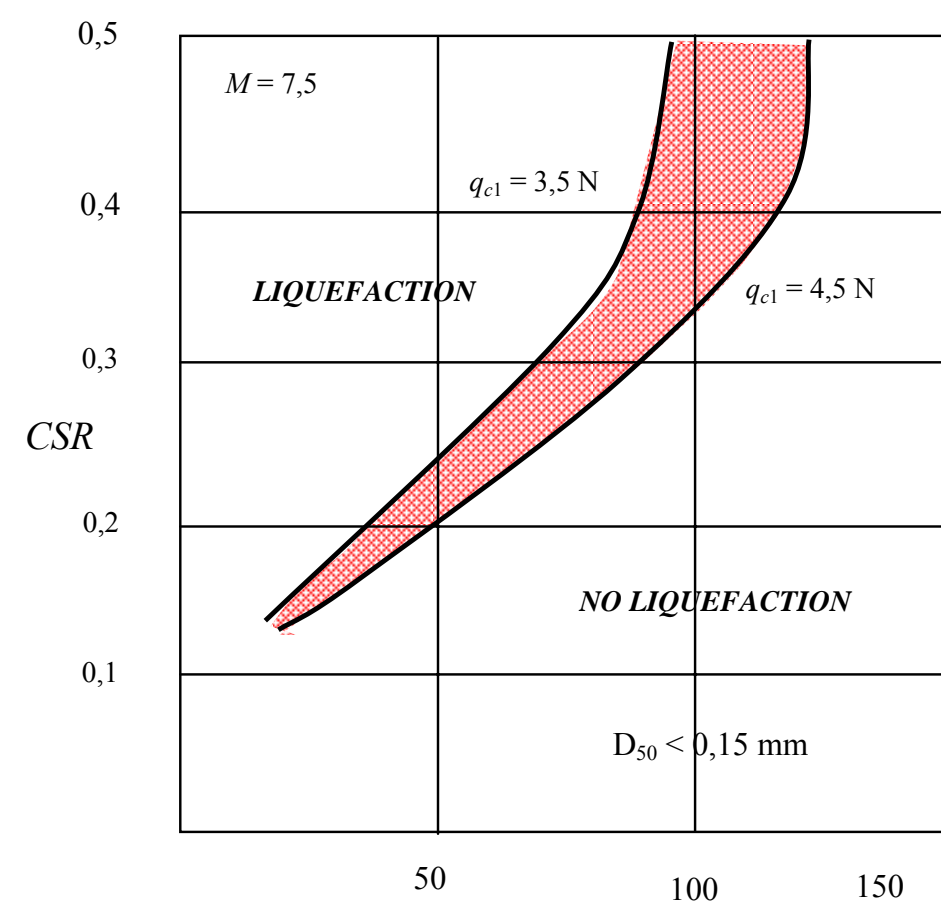

Modified Cone Penetration Resistace for Silty Sand $q_{c 1}\left(\mathrm{~kg} / \mathrm{cm}^{2}\right)$

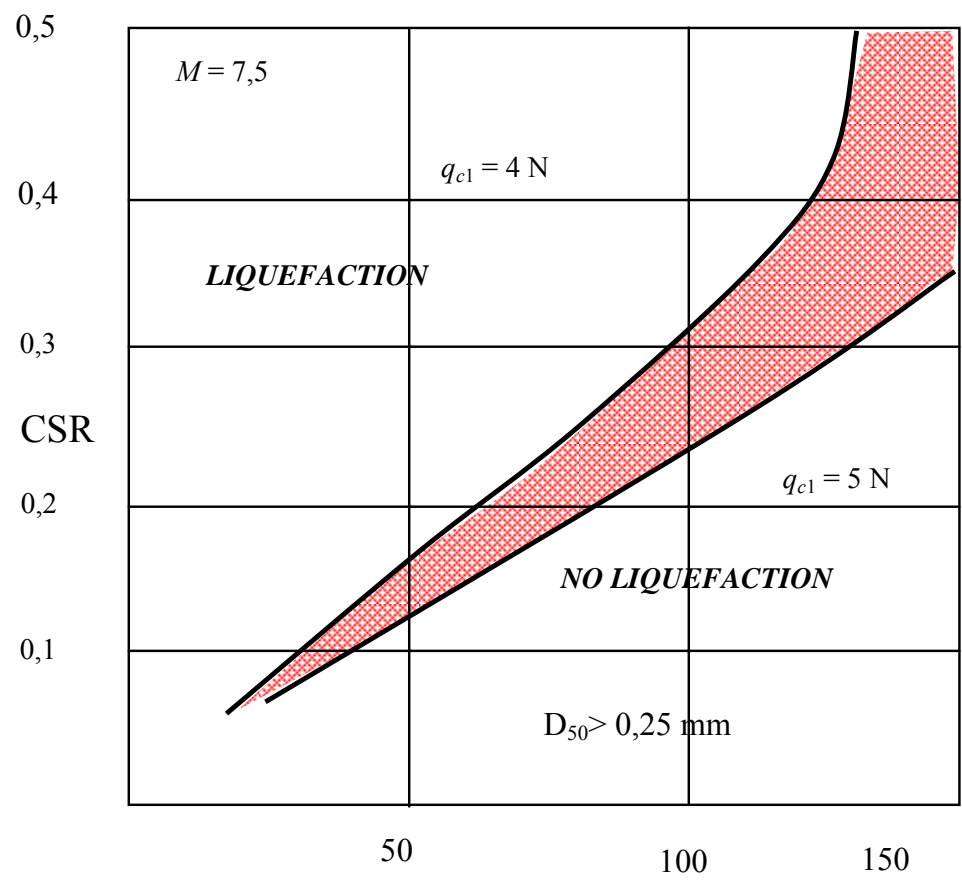

Modified Cone Penetration Resistance for Clean Sand $q_{c 1}\left(\mathrm{~kg} / \mathrm{cm}^{2}\right)$
Gambar 3. Grafik $C S R-$

Perlawanan Konus Terkoreksi Uji

Sondir untuk Tanah Pasir Berlempung (Ground Motion and Soil Liquifaction during Earthquakes, Seed \& Idriss, 1982)

Gambar 4. Grafik $C S R$ -

Perlawanan Konus Terkoreksi Uji Sondir untuk Tanah Pasir Berlempung (Ground Motion and Soil Liquifaction during Earthquakes, Seed \& Idriss, 1982) 
Selain parameter yang telah disebutkan, dalam melakukan analisa potensi likuifaksi dibutuhkan suatu variabel yang diintrepetasikan dalam sebuah persamaan yang dapat mendefinisikan kapasitas tanah sebagai tahanan likuifaksi. Para ahli menginisiasikan tahanan tanah terhadap likuifaksi dengan simbol CRR (Cyclic Resistance Ratio). Robertson dan Wride (1998) membuat sebuah rujukan dalam bentuk grafik hubungan $C R R$ dengan Nilai $q_{c 1}$ terkoreksi pada pasir halus dengan $F C$ (Fine Contents) $\leq 5 \%$ dan grafik ini hanya berlaku untuk magnitude gempa yang terjadi sebesar 7,5 SR. Grafik hubungan antara $C R R$ dan $q_{c 1}$ terkoreksi ditunjukkan oleh Gambar 5.

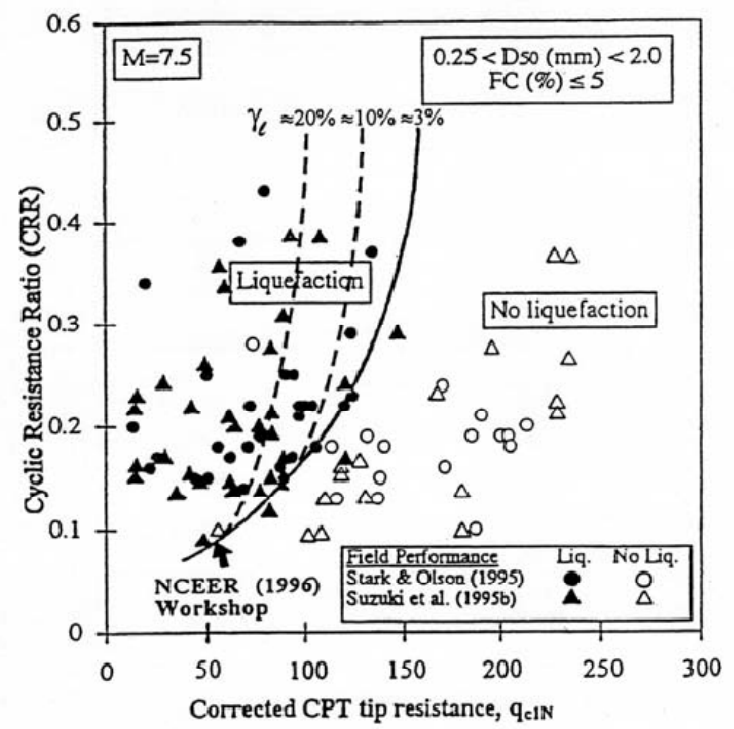

\section{Gambar 5. Hubungan $q_{c 1}$ dan $C S R$ atau $C R R$ terhadap Potensi Likuifaksi} (Robertson and Wride, 1998)

Grafik hubungan $q_{c 1}$ dan $C R R$ atau $C R S$ dari Robertson dan Wride (1998) ini didasarkan pada persamaan yang digunakan untuk memperkirakan nilai $C R R$ pada tanah, yaitu :

Jika, $q_{c 1}<50 \quad \rightarrow \quad C R R_{7,5}=0,833\left(q_{c 1} / 1000\right)+0,05$

Jika, $50<q_{c 1}<160 \rightarrow C R R_{7,5}=93\left(q_{c 1} / 1000\right)^{3}+0,08$

Nilai $C R R$ tanah ini digunakan untuk menentukan faktor keamanan dari perilaku likuifaksi pada tanah, yaitu dengan cara membandingkan antara CSR dengan $C R R$ :

$$
F S_{L}=\left(\frac{C S R}{C R R}\right) M S F
$$

dimana nilai dari magnitude scalling factor $(M S F)$, menggunakan persamaan :

$$
M S F=\frac{10^{2,24}}{M^{2,56}}
$$

\section{METODOLOGI}

\subsection{Investigasi Lapangan}

Investigasi lapangan dilakukan untuk mengambil data tanah di lapangan, dengan pengujian sondir dan menggunakan standar pengujian ASTM D 3441-86. 
Pada penelitian ini, data tanah di lapangan yang dibutuhkan adalah nilai perlawanan konus $\left(q_{c}\right)$ pada kedalaman tertentu dan level muka air tanah (MAT) pada setiap titik pengujian. Data lapangan ini merupakan data primer dibutuhkan untuk melakukan perhitungan dalam menganalisa potensi perilaku likuifaksi pada sedimen tanah. Dalam penelitian ini, uji sondir dilakukan di dua lokasi yaitu GOR Haji Agus Salim dan Lapai, Padang, dimana dilakukan 2 (dua) titik pengujian untuk setiap daerah penelitian.

\subsection{Perhitungan Potensi Likuifaksi}

\subsubsection{Menentukan Jumlah Lapisan dan Penomoran Lapisan}

Jumlah dan penomoran lapisan ditentukan berdasarkan bentang kedalaman tertentu, yang bertujuan untuk mempermudah dalam melakukan analisa dan perhitungan. Dalam penelitian ini, perhitungan dilakukan untuk setiap lapisan dengan rentang data 1 meter kedalaman.

\subsubsection{Mengestimasi Berat Volume Tanah}

Estimasi berat volume tanah dilakukan dengan menggunakan grafik perilaku tanah berdasarkan data sondir seperti yang ditunjukkan Gambar 6, kemudian hasil dari grafik tersebut dikorelasikan ke Tabel 1 untuk mendapatkan berat volume tanah estimasi berdasarkan zona yang diperoleh.

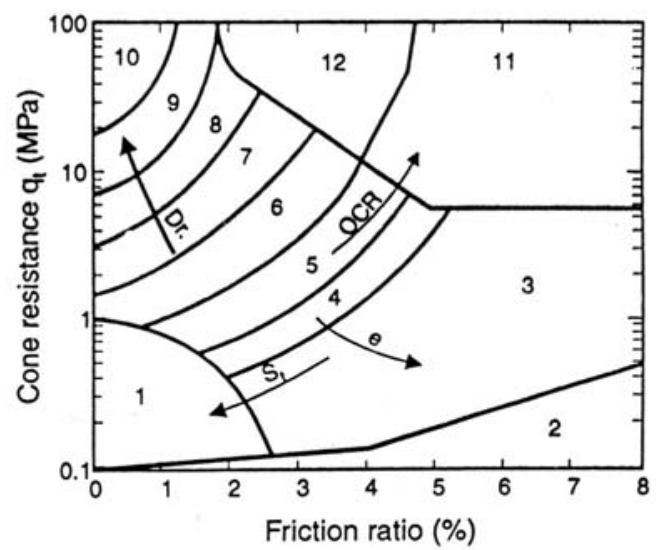

Gambar 6. Grafik Perilaku Tanah Berdasarkan Data (Robertson et al., 1986)

Tabel 1. Berat Volume Estimasi (Robertson et al., 1986)

\begin{tabular}{|c|c|}
\hline \multicolumn{2}{|c|}{ The Estimation of Unit Weight Based Soil Description } \\
\hline Zone & Approximate of Unit Weight $\left(\mathrm{kg} / \mathrm{cm}^{3}\right)$ \\
\hline 1 & 0,00175 \\
\hline 2 & 0,00125 \\
\hline 3 & 0,00175 \\
\hline 4 & 0,00180 \\
\hline 5 & 0,00180 \\
\hline 6 & 0,00180 \\
\hline 7 & 0,00185 \\
\hline 8 & 0,00190 \\
\hline 9 & 0,00195 \\
\hline 10 & 0,00200 \\
\hline 11 & 0,00250 \\
\hline 12 & 0,00190 \\
\hline
\end{tabular}




\subsubsection{Menentukan Tegangan Over Burden Tanah}

Tegangan vertikal pada tanah dihitung dengan rumus:

$$
\sigma_{o}=h \times \gamma
$$

dimana:

$\sigma_{o}=$ tegangan vertikal tanah $\left(\mathrm{kg} / \mathrm{m}^{2}\right)$

$h=$ kedalaman $(\mathrm{m})$

$\gamma=$ berat volume tanah $\left(\mathrm{kg} / \mathrm{m}^{3}\right)$

\subsubsection{Menentukan tegangan efektif tanah}

Tegangan efektif vertikal pada tanah dihitung dengan rumus:

$$
\sigma_{o}{ }^{\prime}=\sigma_{o}-u=(h \times \gamma)-\left(h_{w} \times \gamma_{w}\right)
$$

dimana:

$$
\begin{aligned}
\sigma_{o}{ }^{\prime} & =\text { tekanan efektif tanah }\left(\mathrm{kg} / \mathrm{m}^{2}\right) \\
\sigma_{o} & =\text { tekanan total pada tanah }\left(\mathrm{kg} / \mathrm{m}^{2}\right) \\
u & =\text { tekanan air pori }\left(\mathrm{kg} / \mathrm{m}^{2}\right) \\
h & =\text { kedalaman }(\mathrm{m}) \\
\gamma & =\text { berat volume tanah }\left(\mathrm{kg} / \mathrm{m}^{3}\right) \\
h_{w} & =\text { kedalaman muka air tanah }(\mathrm{m}) \\
\gamma_{w} & =\text { berat volume air }\left(\mathrm{kg} / \mathrm{m}^{3}\right)
\end{aligned}
$$

\subsubsection{Menentukan perlawanan konus terkoreksi (qc1)}

Perlawanan konus terkoreksi dihitung berdasarkan persamaan 1.

\subsubsection{Menentukan Magnitude dan percepatan tanah maksimum (amax)}

Magnitude gempa dan percepatan tanah maksimum digunakan dalam perhitungan cyclic stress ratio. Parameter ini diperoleh dari data gempa Padang Pariaman tanggal 30 September 2009, yaitu magnitude 7,6 SR dengan $a_{\max }$ sebesar $0,28 \mathrm{~g}$.

\subsubsection{Menentukan faktor reduksi tegangan ( $\mathrm{rd}$ )}

Faktor reduksi tegangan dihitung berdasarkan persamaan 3.

\subsubsection{Menghitung nilai Cyclic Stress Ratio (CSR)}

Besarnya nilai cyclic stress ratio ditentukan berdasarkan persamaan 2.

\section{PELAKSANAAN DAN PERHITUNGAN}

\subsection{Pengujian Sondir di Lapangan}

Pengujian sondir dilapangan dilakukan pada 7 titik pengujian yang telah ditentukan. Data investigasi lapangan yang diperoleh ditunjukkan oleh Tabel 1 dan Tabel 2.

Tabel 1. Nilai $q_{c}$ dan $\boldsymbol{R}_{\boldsymbol{f}}$ rata-rata Daerah GOR Haji Agus Salim, Padang

\begin{tabular}{|c|c|c|c|c|c|}
\hline Titik & Layer & $\begin{array}{c}\text { Depth Range } \\
(\mathrm{m})\end{array}$ & $\begin{array}{c}\text { Depth } \\
(\mathrm{cm})\end{array}$ & $\begin{array}{c}\boldsymbol{q}_{\boldsymbol{c}} \\
\left(\mathrm{kg} / \mathrm{cm}^{2}\right)\end{array}$ & $\begin{array}{c}\boldsymbol{R F} \\
(\%)\end{array}$ \\
\hline \multirow{7}{*}{ I } & 1 & $0,0-1,0$ & 100 & 2,50 & 0,67 \\
\cline { 2 - 6 } & 2 & $1,2-2,0$ & 200 & 3,00 & 0,56 \\
\cline { 2 - 6 } & 3 & $2,2-3,0$ & 300 & 12,80 & 0,69 \\
\cline { 2 - 6 } & 4 & $3,2-4,0$ & 400 & 47,60 & 0,88 \\
\cline { 2 - 6 } & 5 & $4,2-5,0$ & 500 & 45,00 & 0,14 \\
\cline { 2 - 6 } & 6 & $5,2-6,0$ & 600 & 72,20 & 0,25 \\
\cline { 2 - 6 } & 7 & $6,2-7,0$ & 700 & 53,60 & 1,63 \\
\hline & 8 & $7,2-8,0$ & 800 & 54,80 & 1,96 \\
\hline
\end{tabular}

\begin{tabular}{|c|c|c|c|c|c|}
\hline Titik & Layer & $\begin{array}{c}\text { Depth Range } \\
(\mathrm{m})\end{array}$ & $\begin{array}{c}\text { Depth } \\
(\mathrm{cm})\end{array}$ & $\begin{array}{c}\boldsymbol{q}_{\boldsymbol{c}} \\
\left(\mathrm{kg} / \mathrm{cm}^{2}\right)\end{array}$ & $\begin{array}{c}\boldsymbol{R F} \\
(\%)\end{array}$ \\
\hline \multirow{7}{*}{ II } & 1 & $0,0-1,0$ & 100 & 3,33 & 1,25 \\
\cline { 2 - 6 } & 2 & $1,2-2,0$ & 200 & 4,00 & 0,96 \\
\cline { 2 - 6 } & 3 & $2,2-3,0$ & 300 & 4,80 & 0,89 \\
\cline { 2 - 6 } & 4 & $3,2-4,0$ & 400 & 24,40 & 1,43 \\
\cline { 2 - 6 } & 5 & $4,2-5,0$ & 500 & 40,00 & 1,00 \\
\cline { 2 - 6 } & 6 & $5,2-6,0$ & 600 & 52,00 & 1,10 \\
\cline { 2 - 6 } & 7 & $6,2-7,0$ & 700 & 63,00 & 0,76 \\
\hline & 8 & $7,2-8,0$ & 800 & 65,00 & 0,80 \\
\hline
\end{tabular}


Tabel 2. Nilai $q_{c}$ dan $\boldsymbol{R}_{f}$ rata-rata Daerah Lapai, Padang

\begin{tabular}{|c|c|c|c|c|c|}
\hline Titik & Layer & $\begin{array}{c}\text { Depth Range } \\
(\mathrm{m})\end{array}$ & $\begin{array}{c}\text { Depth } \\
(\mathrm{cm})\end{array}$ & $\begin{array}{c}\boldsymbol{q}_{\boldsymbol{c}} \\
\left(\mathrm{kg} / \mathrm{cm}^{2}\right)\end{array}$ & $\begin{array}{c}\boldsymbol{R F} \\
(\%)\end{array}$ \\
\hline \multirow{7}{*}{ I } & 1 & $0,0-1,0$ & 100 & 12,17 & 1,59 \\
\cline { 2 - 6 } & 2 & $1,2-2,0$ & 200 & 8,00 & 0,87 \\
\cline { 2 - 6 } & 3 & $2,2-3,0$ & 300 & 1,00 & 0,00 \\
\cline { 2 - 6 } & 4 & $3,2-4,0$ & 400 & 26,40 & 1,16 \\
\cline { 2 - 6 } & 5 & $4,2-5,0$ & 500 & 53,40 & 1,45 \\
\cline { 2 - 6 } & 6 & $5,2-6,0$ & 600 & 60,20 & 1,27 \\
\cline { 2 - 6 } & 7 & $6,2-7,0$ & 700 & 37,20 & 1,61 \\
\hline & 8 & $7,2-8,0$ & 800 & 23,20 & 1,64 \\
\hline
\end{tabular}

\begin{tabular}{|c|c|c|c|c|c|}
\hline Titik & Layer & $\begin{array}{c}\text { Depth Range } \\
(\mathrm{m})\end{array}$ & $\begin{array}{c}\text { Depth } \\
(\mathrm{cm})\end{array}$ & $\begin{array}{c}\boldsymbol{q}_{\boldsymbol{c}} \\
\left(\mathrm{kg} / \mathrm{cm}^{2}\right)\end{array}$ & $\begin{array}{c}\boldsymbol{R F} \\
(\%)\end{array}$ \\
\hline \multirow{6}{*}{} & 1 & $0,0-1,0$ & 100 & 12,83 & 1,15 \\
\hline \multirow{6}{*}{ II } & 2 & $1,2-2,0$ & 200 & 7,40 & 1,09 \\
\cline { 2 - 6 } & 3 & $2,2-3,0$ & 300 & 15,00 & 1,94 \\
\cline { 2 - 6 } & 4 & $3,2-4,0$ & 400 & 25,60 & 1,59 \\
\cline { 2 - 6 } & 5 & $4,2-5,0$ & 500 & 44,20 & 1,31 \\
\hline & 6 & $5,2-6,0$ & 600 & 59,00 & 1,46 \\
\hline & 7 & $6,2-7,0$ & 700 & 26,40 & 1,02 \\
\hline & 8 & $7,2-8,0$ & 800 & 26,80 & 1,94 \\
\hline & 9 & $8,2-9,0$ & 900 & 32,40 & 1,87 \\
\hline
\end{tabular}

\subsection{Contoh Perhitungan (GOR Haji Agus Salim, Titik 1)}

a). Data

- Nomor lapisan $\quad: 1$

- Kedalaman lapisan $\quad: 100 \mathrm{~cm}$

- GWL (ground water level) $\quad: 80 \mathrm{~cm}$

$-q_{\text {c rata-rata }}\left(q_{c}\right) \quad: 3,33 \mathrm{~kg} / \mathrm{cm}^{2}$

- Berat volume tanah $(\gamma) \quad: 0,00175 \mathrm{~kg} / \mathrm{cm}^{3}$

- Magnitudo (M) : 7,6 SR

- $a_{\max } \quad: 274,68 \mathrm{gal}$

- Percepatan gravitasi $(g) \quad: 980 \mathrm{~cm} / \mathrm{det}^{2}$

b). Tegangan Total $\left(\sigma_{o}\right)$

$$
\begin{aligned}
\sigma_{o} & =h \times \gamma=(100 \mathrm{~cm})\left(0,00175 \mathrm{~kg} / \mathrm{cm}^{3}\right) \\
& =0,175 \mathrm{~kg} / \mathrm{cm}^{2}
\end{aligned}
$$

c). Tegangan Efektif $\left(\sigma_{o}{ }^{\prime}\right)$

$$
\begin{aligned}
\sigma_{o}{ }^{\prime} & =\sigma_{o}-u=(h \times \gamma)-\left(h_{w} \times \gamma_{w}\right)=(100 \times 0,00175)-[0,000981 \times(100-80)] \\
& =0,097 \mathrm{~kg} / \mathrm{cm}^{2}
\end{aligned}
$$

d). Normalisasi Perlawanan Konus $\left(q_{c 1}\right)$

$$
\begin{aligned}
q_{c 1} & =C N \times q_{c}=1,60 \times 3 \\
& =5,33 \mathrm{~kg} / \mathrm{cm}^{2}
\end{aligned}
$$

e). Reduksi Tegangan Siklik $\left(r_{d}\right)$

$$
\begin{aligned}
r_{d} & =\frac{1,0-0,4113 z^{1,5}+0,04052 z+0,001753 z^{1,5}}{1,0-0,4177 z^{0,5}+0,05729 z-0,006205 z^{1,5}+0,00121 z^{2}} \\
& =\frac{1,0-0,4113(1)^{1,5}+0,04052(1)+0,001753(1)^{1,5}}{1,0-0,4177(1)^{0,5}+0,05729(1)-0,006205(1)^{1,5}+0,00121(1)^{2}} \\
& =0,994
\end{aligned}
$$

f). Cyclic Stress Ratio (CSR) (Seed \& Idriss)

$$
\begin{aligned}
C S R & =0,65 \times\left(\frac{a_{\max } \times \sigma_{o}}{g \times \sigma_{o}{ }^{\prime}}\right) \times r_{d}=0,65 \times\left(\frac{274,68 \times 0,175}{980 \times 0,097}\right) \times 0,994 \\
& =0,328
\end{aligned}
$$




\subsection{Perhitungan Likuifaksi}

\subsubsection{Menentukan Potensi Likuifaksi berdasarkan Hubungan CSR - Perlawanan Konus Terkoreksi}

Dari hasil perhitungan yang diperoleh, dilanjutkan dengan memplot data hasil perhitungan antara nilai CSR dan nilai perlawanan konus terkoreksi pada Gambar 4. Hasil yang diperoleh terlihat seperti pada Gambar 7.

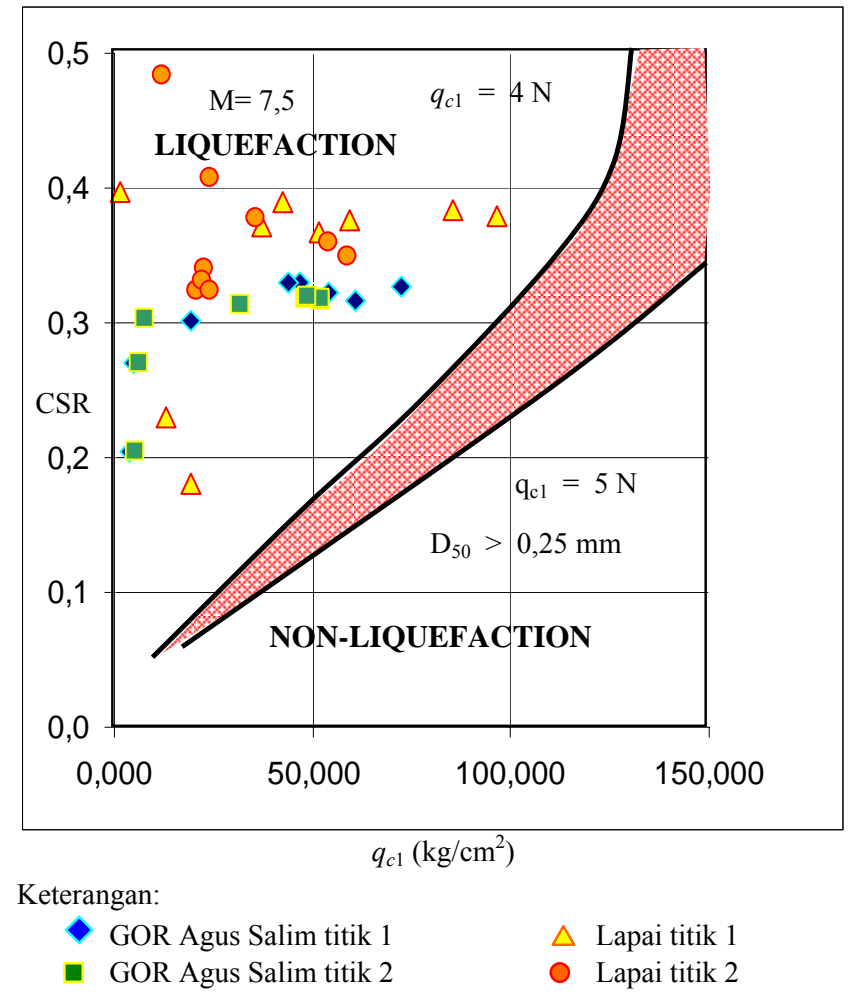

Gambar 7. Grafik Hubungan antara CSR dan $q_{c 1}$

Dari gambar 4.1, terlihat bahwa cyclic stress ratio dan perlawanan konus terkoreksi dati tiap kedalaman tinjaun menunjukan tanah berpotensi terhadap likuifaksi. Hal ini ditunjukan dengan sebaran titik pada grafik di daerah likuifaksi. Sehingga dapat diambil kesimpulan dari hasil perhitungan potensi likuifaksi dengan tinjaun 2 daerah tersebut dapat dinyatakan terjadi Likuifaksi.

\subsubsection{Menghitung Nilai Magnitude Scalling Factor (MSF)}

Besarnya nilai magnitude scalling factor ditentukan berdasarkan persamaan 6, tergantung dari nilai perlawanan terkoreksinya.

\subsubsection{Menghitung Nilai FSL(Safety Factor)}

Besarnya nilai $F S_{L}$ ditentukan berdasarkan persamaan 5. Nilai $F S_{L}$ yang digunakan untuk menyatakan suatu deposit tanah aman terhadap likuifaksi adalah $\geq 1,50$. Hasil perhitungan nilai $F S_{L}$ ditunjukan Gambar 8 dan Gambar 9. 


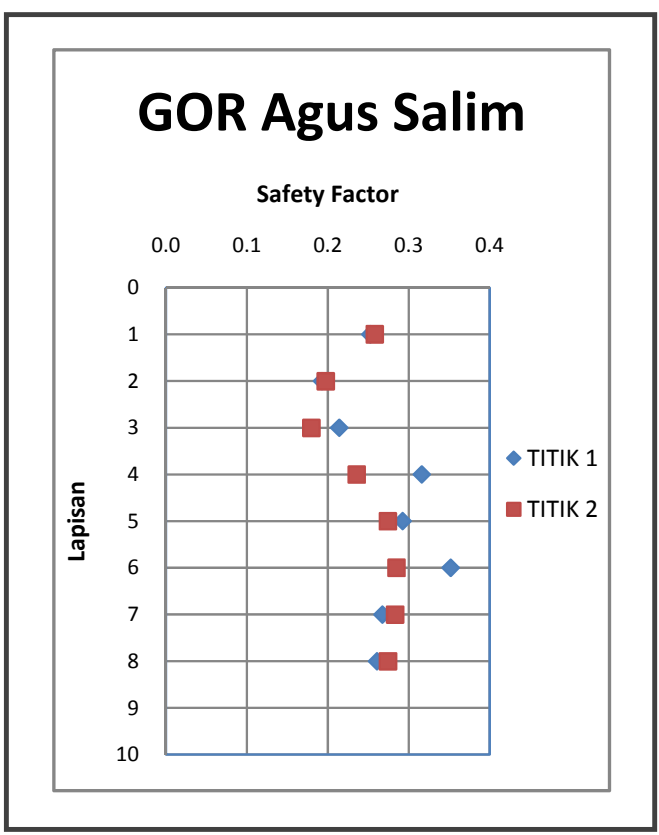

Gambar 8. Angka Keamanan vs Lapisan pada Daerah GOR Haji Agus Salim

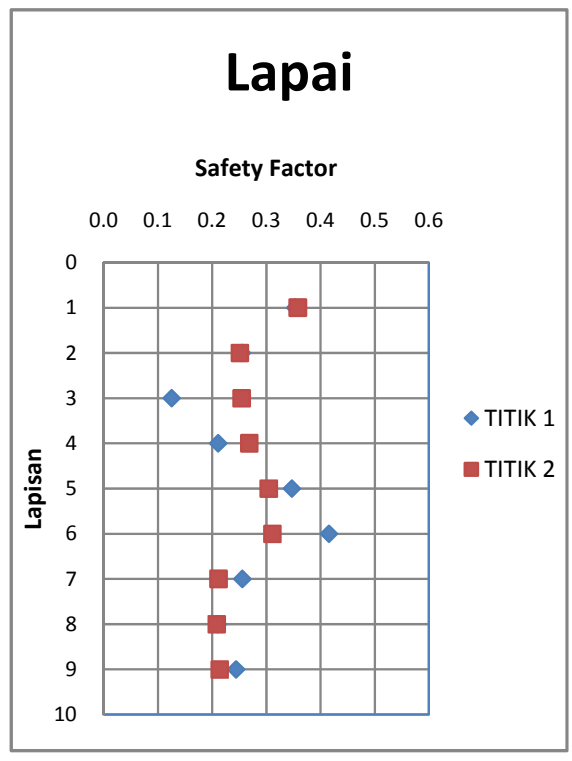

Gambar 9. Angka Keamanan vs Lapisan pada Daerah Lapai

\section{KESIMPULAN DAN SARAN}

\subsection{Kesimpulan}

Dari data lapangan dan hasil perhitungan yang diperoleh, dapat disimpulkan bahwa sedimen tanah di kawasan GOR Haji Agus Salim dan Lapai, Padang memiliki karakteristik sebagai berikut :

1. Tipikal tanah pada daerah tersebut secara umum didominasi oleh jenis tanah lanau kepasiran (sandy silt) dan pasir berlanau (silty sand).

2. Muka air tanah yang dangkal (dari permukaan) sangat mempengaruhi tanah terhadap potensi likuifaksi. Dengan demikian, akan mempercepat naiknya tegangan air pori.

3. Melihat dari hasil perhitungan, daerah yang aman untuk perletakan pondasi diperkirakan pada nilai penetrasi konus $>100 \mathrm{~kg} / \mathrm{cm}^{2}$.

4. Daerah penelitian memiliki potensi besar terhadap likuifaksi, hal ini ditunjukan oleh nilai safety factor yang kecil dibandingkan dengan nilai aman yang telah ditentukan.

\subsection{Saran}

Berdasarkan hasil penelitian yang diperoleh, disarankan beberapa hal berikut:

1. Hasil perhitungan yang diperoleh sebaiknya dibandingkan dengan metode perhitungan lainnya, seperti perhitungan menggunakan data pengujian laboratorium atau pengujian penetrasi standar (SPT).

2. Jumlah titik pengujian sondir diperbanyak dalam melakukan analisa likuifaksi, dengan tujuan agar terdapat data pembanding antara satu titik pengujian dengan titik lainnya.

3. Sistem pondasi yang digunakan sebaiknya pondasi dalam hingga mencapai kedalaman yang aman terhadap perilaku likuifaksi pada sedimen tanah tersebut.

4. Perbaikan pada daerah likuifaksi dapat dilakukan dengan berbagai cara seperti deep compaction, sand drain dan lain sebagainya. 


\section{Analisa Potensi Likuifaksi Berdasarkan Data Pengujian Sondir (Studi Kasus GOR Haji Agus Salim dan Lapai, Padang)}

\section{DAFTAR PUSTAKA}

Harnaldo, (2008), Analisa Prilaku Likuifaksi pada Sedimen Tanah Padang Industrial Park (PIP) Berdasarkan Pengujian Sondir. (Skripsi Sarjana yang tidak dipublikasikan, Jurusan Teknik Sipil, Fakultas Teknik, Universitas Andalas, 2008).

Lune, T., Robertson, P.K., and Jhon J.M. Powel, (1997), Cone Penetration Testing in Geotechnical Practice, T.J. International, UK.

Kramer, Steven.L., Geotechnical and Earthquake Engineering, Prentice Hall, New Jersey, USA.

Seed, H. Bolton, (1982), Ground Motions and Soil Liquefaction During Earthquakes, Earthquake Engineering Research Institute.

Shibata, Toru and Wanchai Teparaksa, (1988). Evaluation of Liquefaction Potensials of Soils using Cone Penetration Tests, Journal of Japanese Society of Soil Mechanics and Foundation Engineering, June, 1988, Vol. 28, pp. $49-60$.

Youd, T.L. and I.M. Idriss, (2001), Liquefaction Resistance of Soils: Summary Report from The 1996 NCEER and 1998 NCEER/NSF Workshop on Evaluation of Liquefaction Resistance of Soils: Journal of Geotechnical and Geoenviromental Engineering, ASCE, April, 2001, Vol. 127, No. 4, pp. $297-313$. 